\title{
Four hundred years of niche construction in the western Solomon Islands
}

\author{
Peter Sheppard
}

\section{Introduction}

In a recent issue of Current Anthropology (Fuentes and Wiessner 2016), dedicated to how anthropology might bridge or reintegrate across the evolutionary/scientific and constructivist or humanistic approaches which seem to divide us, the editors offer the extended evolution synthesis (EES) and niche construction theory (NCT; Laland et al. 2014) as a way forward. Fuentes states that 'humans construct ecological, technical and cultural niches that influence the structure of evolutionary landscapes' and argues:

A contemporary evolutionary approach has to treat what humans do and experience as a complex system that has specific histories, has inherited ecologies and institutions, and includes a myriad of categories of action and perception as they relate to the interactions between individuals, groups, and the communities in which they exist. (Fuentes 2016:S14-S15)

This would appear to mirror, albeit coming from the opposite side of the 'divide', the move by Hodder (2012), to mesh consideration of materiality, actor-network theory and notions of entanglement with evolutionary theory. Both approaches would appear to be highlighting the importance of historical contingency, which underlies both biological evolutionary theory and culture history. For those interested in proximate explanations of the archaeological record either approach could be methodologically useful, although both can lead into highly detailed explanatory narratives. This leaves one with the question as to how such a narrative differs from a traditional detailed culture history. In the following I will briefly sketch out an historical narrative 'explaining' or describing, within the terms of the EES-NCT framework proposed by Fuentes (2016), the culture history of the western Solomon Islands and consider to what extent it led me to enrich my understanding of the archaeological and historical record. In particular I will focus on how the situation-specific developments in Roviana Lagoon have altered the cultural environment or niche to which Roviana and neighbouring societies have had to respond or adapt. A combination of an inherited set of geographical and environmental features of the lagoon and inherited Austronesian cultural schemata have led to the development of a cultural niche employing headhunting, which has created a powerful selective force. Neighbouring societies have either adopted this cultural form or have fallen victim to it, dramatically changing regional demography and culture as seen in language distribution. Ultimately these forces come into conflict with, and succumb to, expanding global capitalism. 


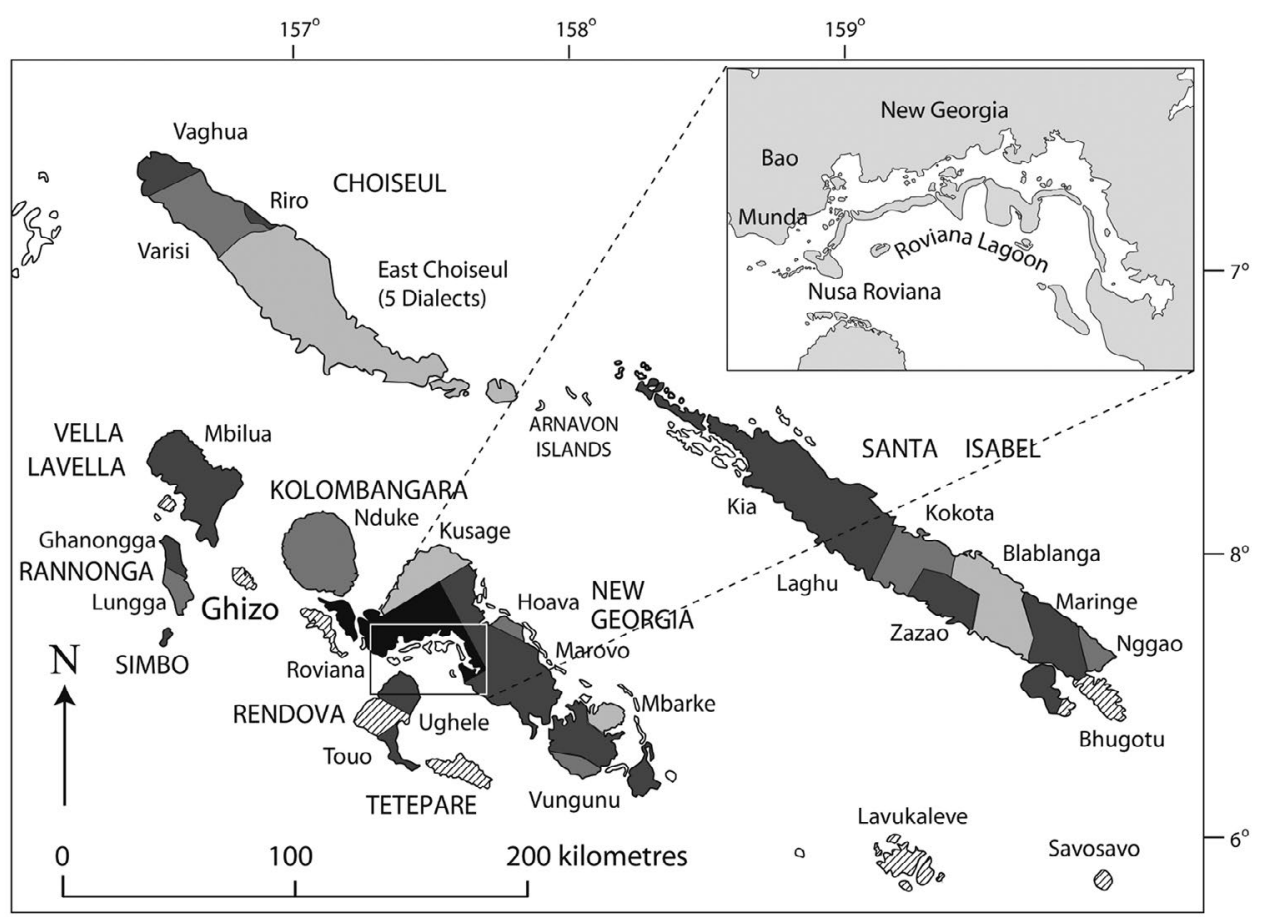

Figure 8.1. The western Solomon Islands and its languages.

Source: Peter Sheppard.

\section{The western Solomons}

In the 19th century, the western Solomons (Figure 8.1) was an area of considerable linguistic diversity; yet it had an overarching cultural tradition or community of practice (Thomas 2009) centred on a political economy sharing systems of exchange, religion and authority. A total of 24 Austronesian and four Non-Austronesian (NAN East Papuan) languages are found within a distance of $425 \mathrm{~km}$ along the chain of islands which make up the region, with Roviana forming the largest language group (Lewis et al. 2016). Crossing these linguistic boundaries, both Austronesian and NAN, was much commonality in material culture. In the 19th century European traders noted the importance of particular forms of shell rings which served as means of exchange in commodity transactions as well as means of social exchange and symbolic marking of many types (Aswani and Sheppard 2003). Headhunting, both for heads and captives, was endemic and large war canoes (tomoko in Roviana), holding up to $30 \mathrm{men}$, were found throughout the region (Woodford 1909). Ancestral skull shrines, which, although varying somewhat in form throughout the region (Figure 8.2), shared very similar components and functions. Together these items were key components of a distinctive western Solomon culture complex. How then did this complex form in the context of the underlying cultural diversity signalled by language? An EES perspective would suggest the pattern seen in the western Solomons involves a complex history of evolutionary forces generating both cultural diversity and homogeneity, within a specific physical ecology or geographical setting (i.e. arrangement of islands and lagoons, soil types, raw material distributions, etc.) which itself frames patterns of interaction into which different evolutionary lineages can contribute novel cultural variation at different times. As these histories of interaction are worked out, the cultural environment may change and the selective environment or niche in which variety generating or reducing interaction takes place will vary. I argue that this has taken place in the western Solomons, with early variety generating forces overtaken in the last 400 years by forces selecting for cultural conformity. 


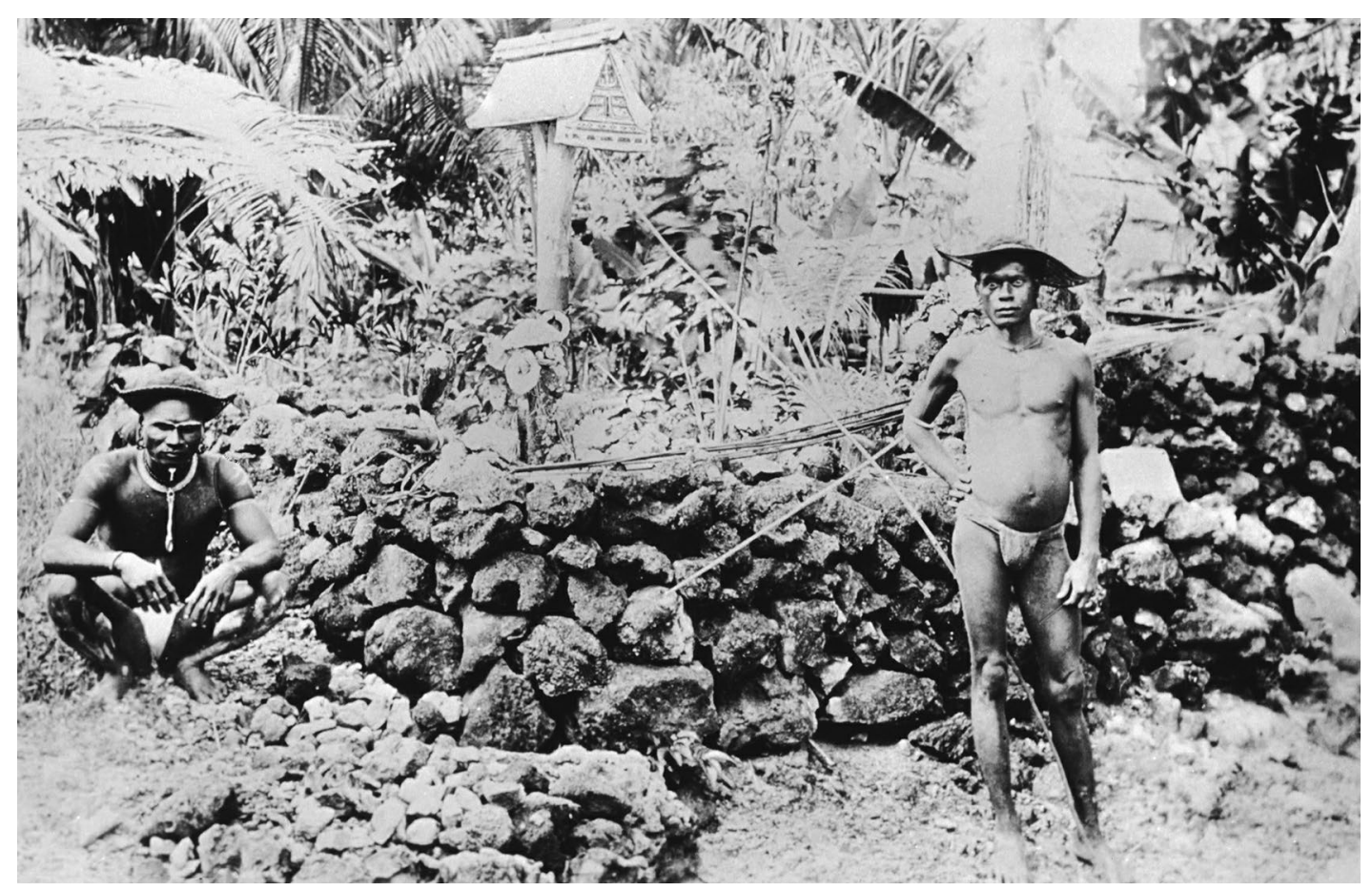

Figure 8.2. Roviana ancestral skull shrine.

Source: Reverend George Brown 1899, courtesy Auckland Methodist Archives.

\section{Inherited ecologies: Regional geography and resources}

At the centre of the western Solomons is the large Roviana Lagoon, extending $40 \mathrm{~km}$ along the south-west coast of New Georgia. In addition to being central, and closely networked to neighbouring islands (Sheppard and Walter 2008), Roviana is rich in natural resources of high productivity as attested by the high modern population density and number of villages. It is the most densely populated area in the western Solomons outside of the provincial capital Ghizo. The resources of the lagoons are rich (Aswani 1997) and the region must rank amongst the most productive in the western Solomons. The lagoons are enclosed by upraised barrier reefs and the interiors of many of these contain rich dark garden soils. Their chemistry confirms they are capable of supporting highly productive intensive horticulture (Furusawa and Ohtsuka 2009) unlike mainland soils. The large villages, except that along the Munda shore, are located on the barrier islands at the passages between islands. In summary, Roviana would appear to be a most, if not the most, advantageous area for human settlement in the western Solomons.

Two material resources become important in western Solomons' history: fossil giant clam (Tridacna) shell and shell of hawksbill turtles. Fossil Tridacna is found in the upraised reefs of the barrier islands. This shell was used to make shell money and valuables (Aswani and Sheppard 2003). Despite Roviana being described as a 'mint', it is not clear if Roviana or any other area is especially favoured in this resource. Early accounts such as that of Ribbe (1903:292) and others (Richards and Roga 2004; Welsch 1998) indicate Tridacna is found throughout the tectonically active western Solomons. Hawksbill shell, called tortoiseshell by early Western traders, was traditionally used to make decorative body ornaments in the western Solomons. Turtles are found throughout the Solomons and were commonly hunted. The largest nesting site in the South-West Pacific is on the Arnavon Islands in the strait between Choiseul and Santa Isabel (Hamilton et al. 2015), $100 \mathrm{~km}$ north-west of Roviana. In the late 19th century this area became the major source of 'tortoise' shell in the western Solomons (Bennett 1985). 


\section{Inherited cultural schema: Categories of action and perception}

The western Solomons was probably initially settled in the Late Pleistocene (Wickler 2001) by a low density foraging or wild food producing population speaking a NAN (Dunn et al. 2005) language, which over time diversified in place (Ross 2010). By the late 19th century only two NAN-speaking groups remained in the western Solomons: a small group on the south-eastern coast of Rendova (Touo) and speakers of Mbilua on Vella Lavella.

Today most people in the region speak related Austronesian languages forming part of the North-West Solomonic family (Ross 1988), which extends north into the Bismarck Archipelago. It is difficult to determine when Austronesians moved from the Bismarcks into the Solomons. Presumably it is marked by the spread of the Lapita cultural complex associated with the appearance, in the Bismarcks c. 3500 cal BP, of domesticates, fully developed food production (Spriggs 1997:61) and new technologies including ceramics. In the western Solomons, late Lapita sites with ceramics similar to those found in New Ireland (Garling 2003) appear from c. $2600 \mathrm{cal}$ BP (Sheppard and Walter 2006). This movement finds support in the linguistic evidence, which shows Proto North-West Solomonic most closely related to the languages of south New Ireland and moving into the western Solomons after it diverged from Proto Oceanic (Ross 2010).

These new people, or new Austronesian cultural tradition, would presumably have replaced the previous foraging lifeway in a short period of time, given new enhanced food production capability. Once established, Proto North-West Solomonic broke up over the following millennia into the many languages of the western Solomons. Linguistics indicates very complicated sets of local histories leading to the extreme diversity seen today (Ross 2010:265). In a few locations, the NAN language survived, although speakers must have rapidly adopted much of this new cultural formation. For example, on the relatively large island of Vella Lavella, where NAN is exclusive, the presence of late Lapita sites like those found in Roviana (Sheppard et al. 2010), suggests either a failed settlement by Austronesian speakers or the adoption of the presumed Austronesian late Lapita lifeway but not the language.

Austronesian language and tradition involved not just a new foodway but also the introduction of new cultural schema or systems (Shore 1996) of core cultural values and meanings common to much of the Austronesian world (Fox 1995; Reuter 2006; Scaglion 1996). Study of terms and meanings in language is the only effective approach to tracing the history of terms and creating hypotheses regarding meaning (Pawley and Ross 2006). However, reflexes of Austronesian terms may be polysemous or have multiple meanings or senses which can seem in English to be more or less related (Pawley 2005). Thus when we see considerable coherence within a term, even across a large number of languages related at some time depth, what we are seeing is inheritance of a semantic field providing opportunities to select or elaborate meanings within new contexts. Given this caveat, and in the absence of any detailed reconstructions for North-West Solomonic, I would suggest the following as some key semantic fields related to core cultural schema at the Proto Oceanic level, which would have been part of the North-West Solomonic cultural inheritance.

Austronesian societies emphasise notions of precedence (Vischer 2009) and order found both in histories of movement and place, and in genealogy (Fox 1997). Into this are set both bilateral and lineal systems of social relationships with what Fox (1995) calls apical demotion as a means to develop hierarchy by promoting lineages seen to be closer to apical ancestors. Semantic fields of hierarchy have been constructed for Proto Oceanic by Pawley (1982) who identified terms for 'chief' and the firstborn son of the chief which were subsequently revised by Lichtenberk (1986) who proposed terms for 'big, great person' and oldest child. Underlying and animating these terms and relationships are the values of mana and tabu which can be reconstructed back to Proto Oceanic (Kirch and Green 2001:239). As Keesing (1985) and Burt (1988) report, these terms reflect complex fields of meaning. Keesing (1985:203) describes the Proto Oceanic term mana as a: 
stative verb, with meanings of 'be efficacious, be true, be realized, be potent,' and the implication that such efficacy and potency was a result of blessings or protection or potentiation by ancestral or other spirits.

In a similar vein the term tabu refers to a field of meanings which, according to Keesing (1985:204), has as its basic Proto Oceanic meaning the relational concept of 'off limits' and is used to structure relations of people to people and people to things. Burt (1988:75) notes that:

Ultimately $a b u$ in Kwara'ae appears to be a way of dealing with power, of controlling not just the spiritual and reproductive powers of men and women but also the political power to which these powers contributed.

Both terms then are fundamental terms expressing and structuring agency (Keesing 1985:204) in the Proto Oceanic social world, which included both the living and ancestors; thus extending relationships of agency to the ancestors. Ultimately through these inherited terms we see the potential for expressing differential access to power and the development of hierarchy in Austronesian societies like Roviana.

Another inherited structuring principle, which is important historically in the Solomons and presumably has ancient roots, is the distinction between coast and bush. In particular the distinction made between people of the interior and those of the coast (Miller 1980; Roe 2000). This relates in part to the importance of topogenies and origin stories in Austronesian societies (Fox 1997) that are often told in terms of movements from the interior to the coast, even, as Miller (1980) points out, on very small islands like Simbo where the distances can be less than a kilometre. These topogenies, or sequences of named places, map people onto the landscape and like genealogies define groups, yet at the same time appear to reflect a real tension over coastal access and resources. Where interior populations are found today, in islands like Malaita, the coast/bush dichotomy has historically been very important, with significant trade in resources between the regions (Roe 2000). Modern populations in the western Solomons are essentially coastal; however, some of their 19th-century ancestors lived in the bush and thus for them even recent history is one of movement to the coast to take advantage of opportunities found there; something which may have been going on for millennia.

\section{Evolution of the Roviana chiefdom}

Following the late Lapita tradition, which is estimated to last until c. $2000 \mathrm{BP}$, the archaeological record in the western Solomons is blank until $800 \mathrm{BP}$ when dated inland sites appear (Sheppard and Walter 2009). In Roviana, the Bao Period, beginning by at least $1200 \mathrm{CE}$, is marked by the appearance of isolated 'shrines' on the ridges to the back of the coastal flats on the mainland. These shrines consist of earthen platforms faced with basalt slabs. Often there is a small depression or stone-lined box set into the platform at one end (Figure 8.3). Adjacent to the platform is commonly found one or more large flat 'table' stones supported on a set of cobbles. Excavation in and around these sites shows they are completely clean of cultural material and there is no evidence of associated occupation. Most notable is the absence of any hearth or surface ovens (oputu). Shrines of this form are also found in a few locations on the barrier islands of Roviana Lagoon where they are marked by the presence of large $(150 \mathrm{~kg}+)$ basalt slabs transported from the interior of New Georgia. The oldest, dated c. $1200 \mathrm{CE}$, is $2 \mathrm{~km}$ into the hills of the Bao area to the back of Munda. This shrine and region is considered to be a Roviana origin location, associated in oral tradition with the chief Ididubanara who traditionally moved down to the lagoon sometime in the early 17th century, based on genealogy (Aswani 2000; Hall 1964; Nagaoka 1999). Accordingly, a shrine site (Site 79) on the barrier island of Nusa Roviana containing abundant basalt construction is associated in oral tradition with Ididubanara; using radiocarbon, it dates to after the mid-14th century (Sheppard et al. 2000). 


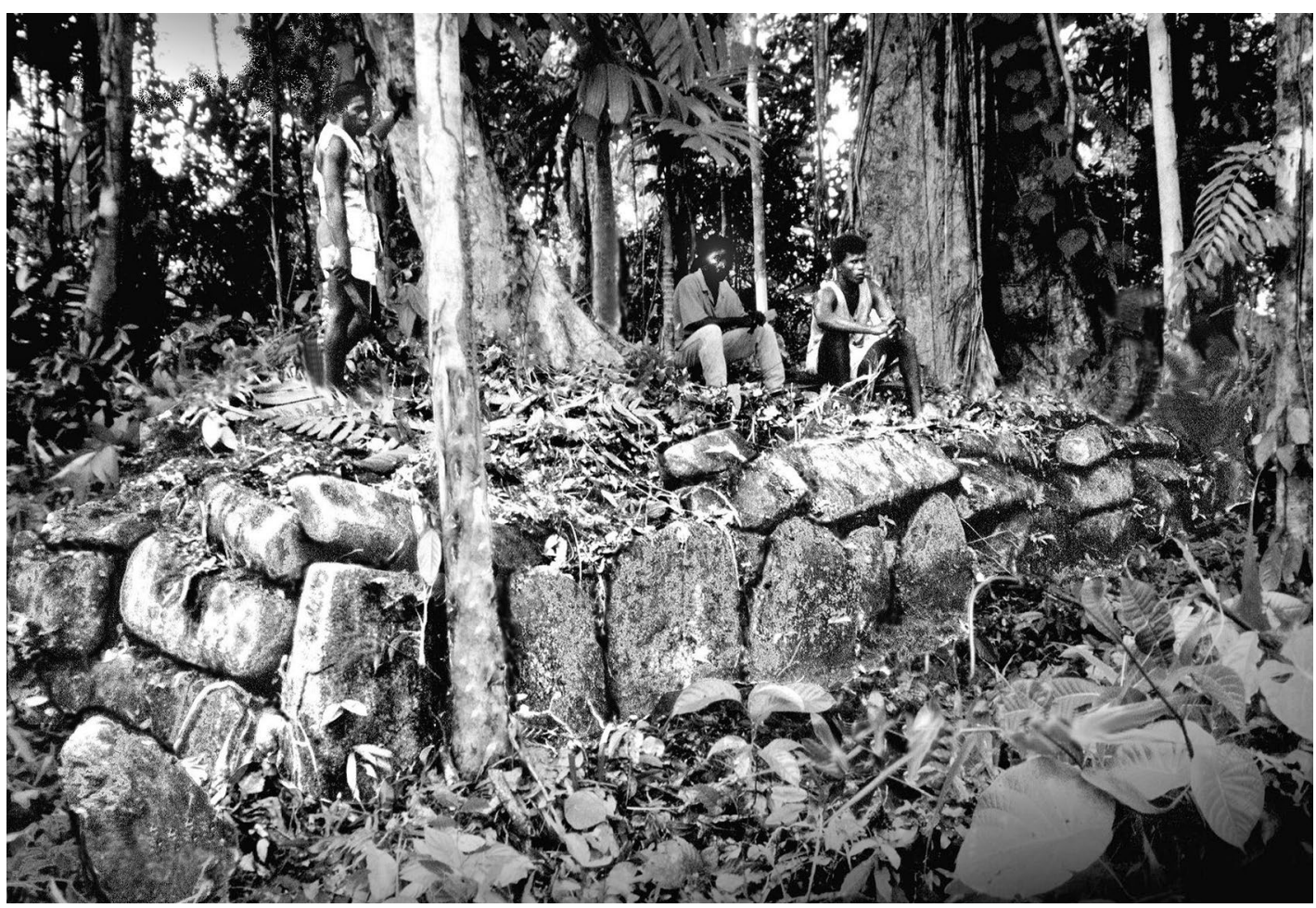

Figure 8.3. Early Bao Period shrine in Roviana.

Source: Peter Sheppard.

In the late 16th or early 17 th century, we see the sudden appearance of a new type of shrine associated with historic Roviana, common on the barrier islands in or near settlements. At their simplest, these are small platforms made of coral cobbles; often a number of small platforms are aggregated together and surrounded with an enclosure. Small cists on these platforms are generally made of sheet coral and typically contain human skulls, shell rings and other shell artefacts, or in historic sites, metal and glass objects. The ground around these platforms is densely covered with shell and animal bone, which are the remains of food offerings. An oven (oputu) composed of basalt cobbles is always nearby. Photographs of Roviana shrines usually show a wooden superstructure such as a post supporting a box containing skulls (Figure 8.2) and it may be that the current sheet coral boxes on the platforms are constructions enclosing skulls after the original wooden structures rotted. Unlike the earlier faced shrines, isolated away from evidence of residential occupation, these later forms are usually found in close proximity to house platforms and within village contexts. The distribution on the barrier island of Nusa Roviana, which is traditionally considered to be the focal point of the Roviana chiefdom, is a good example.

Nusa Roviana is located in the centre of Roviana. Unlike the other islands, it has a high, steepsided narrow central ridge, providing a good defensive feature looking out over approaches to the lagoon. The island is densely carpeted with the remains of continuous settlement covering the coastal flats around the ridge (Sheppard et al. 2000; Sheppard et al. 2002; Walter and Sheppard 2001). The ridge itself contains a large fortified complex which extends along the ridgetop for $700 \mathrm{~m}$. The fortification consists of three major (up to $3 \mathrm{~m}$ high) stone and earth walls and a deep rock cut ditch at the southern end. These cut across the ridge and enclose a series of nine named shrines. Sequences of narrow terraces descend the steep slopes to the east and west. Dates on shell from under the walls indicates construction beginning after 1500 CE (Sheppard et al. 2000). 


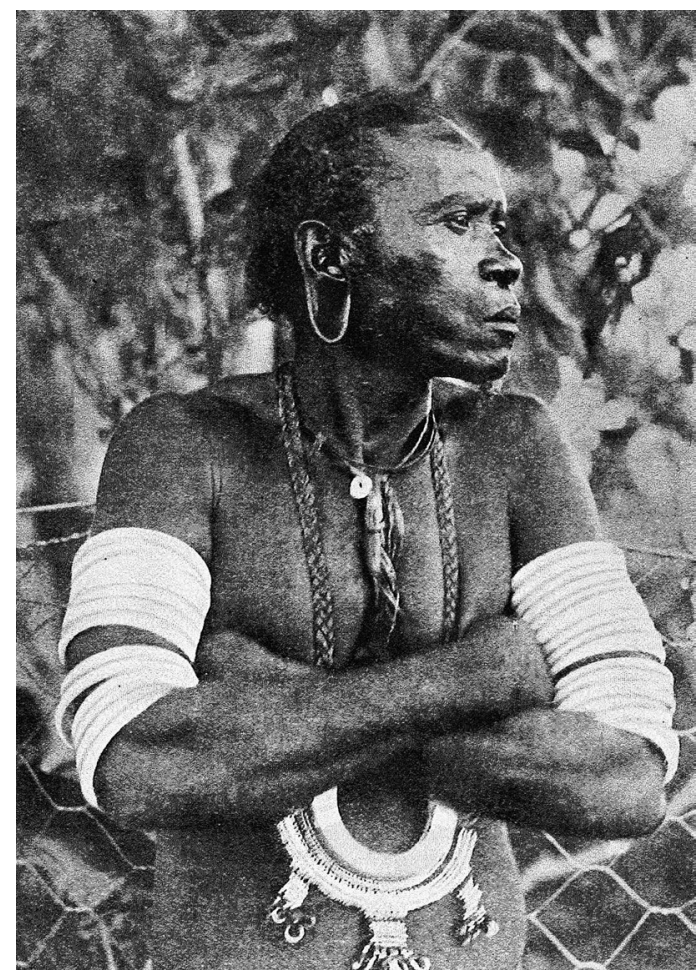

Figure 8.4. The Roviana chief $(\mathrm{H})$ Ingava wearing a bakiha rapoto and hokata (arm-rings), both forms of poata.

Source: Edge-Partington 1907.

How should we interpret this dramatic change which correlates with the establishment of the Roviana chiefdom as it was known in the 19th century? Oral history relates that the inland people from Bao, under Ididubanara, moved to the coast to more easily procure the fossil Tridacna needed to manufacture shell rings. Ididubanara fought with the people who lived on Nusa Roviana and the islands, chasing them from the lagoon, thus establishing Roviana with a base on Nusa Roviana (Aswani and Sheppard 2003). Subsequent oral tradition recounts what Fox (1995) might describe as apical demotion, when chiefs (banara) within a particular lineage became mateana (meteor, or used to translate 'angel' in English (Waterhouse 1949:73)), and at the location of a shrine (Zare) in the Nusa Roviana hillfort ascended to heaven or descended into the earth. These individuals founded the main chiefly lineage of Roviana two generations after Ididubanara (Aswani 2000).
Status in Roviana is signalled by a chest ornament known as bakiha rapoto which consists of a decorated bakiha or highvalue shell ring made from fossil Tridacna (Figure 8.4). In 1908, Hocart reported these rings were made from fossil Tridacna that was the food waste of tamasa (gods or spiritbeings; Hocart n.d.(b)), giving them an association with ancestral spirits. They were used to inaugurate chiefs as children and placed under their skulls when they were finally placed in the ancestral skull shrine. These rings not only had powerful ritual and symbolic associations, they were also the most valuable of a hierarchy of shell valuables known as poata. Poata could be exchanged to mark social relationships and occasions (e.g. marriage, peace settlements, rewarding warriors, etc.) but also used to pay for any kind of commodity (e.g. canoes or taro), services or knowledge such as magical spells (Aswani and Sheppard 2003; Thomas 1991). These poata made possible a regionally networked economy in commodities (e.g. purchase of food for feasts, etc. (Sheppard and Walter 2013)). Chiefs were ultimately powerful and able to command respect if they had access to enough poata to make feasts, cover the cost of social exchanges of their people, build canoe houses and large 30-man war canoes, and reward warriors after a successful headhunting expedition (Hocart 1931, n.d.(a)).

Headhunting (see also Chapter 7 this volume) was central to Roviana culture and political economy. Chiefs mounted very large headhunting raids involving, on occasion (in 1893, for example), as many as 500 men, large numbers of rifles and 22 war canoes (tomoko) (Somerville 1897). Chiefs funded the construction of tomoko at a cost of the equivalent of 1 poata per rib (i.e. 11 poata or 5500 copra in 1908 (Hocart n.d.(b)). Following a successful headhunt warriors were rewarded with a feast and poata and the heads were hung in the rafters of the chief's canoe house. Early traders describe raids returning large numbers of heads with 93 reported from a raid in 1844 (Shineberg 1971:62). This activity underwrote the power of chiefs, as the 
skulls were a materialised display of chiefly mana or efficacy provided by the ancestors, as were the living captives (McDougall 2000) who provided the means for ritual sacrifice (Hocart 1931) and labour for such things as shell valuable production.

By the 19th century Roviana society had evolved, drawing on inherited Austronesian cultural schema, into a powerful hierarchical chiefly society established in an optimal location both in terms of food resources and geographical centrality. Through respect for ancestors and the mana they could bestow, apical demotion which privileged certain lineages, the elaboration of headhunting as a means of demonstrating ancestral blessing and mana, and the development of a shell valuable economy which provided a mechanism for running both a social exchange economy and a trade in commodities, Roviana developed a society with strong power differentials. This required continual predatory expansion in order to obtain heads and captives, thus profoundly altering the cultural environment or niche impacting neighbouring societies.

But what were the drivers for this evolution? The shrine record suggests an abrupt change which correlates with oral tradition of movement from the interior (Aswani and Sheppard 2003). However, some of the elements of the headhunting complex such as the tomoko and the shell valuable tradition existed outside of Roviana at about this time. The Spanish on Santa Isabel in $1568 \mathrm{CE}$ described what can only be tomoko. 'Their canoes are very well made and very light ... shaped like a crescent, the largest holding about thirty persons' (Amherst and Thomson 1901:109). They also observed leaders on Isabel wearing white chest ornaments made of 'white alabaster', probably fossil Tridacna. Developments at this time in Roviana were thus not simply local innovations but pulled on older regional traditions of material culture. The changes in Roviana itself appear, however, to be fundamentally the result of competition between bush and coastal groups for rich coastal resources in what was an optimal location. Defence of this location required the creation of a hill fort on a very well situated and uniquely defensible ridge on Nusa Roviana. These developments, specific to Roviana, would, I suggest, promote changes toward hierarchical social organisation crafted out of the cultural schemata or traditions outlined above.

\section{Expansion of the predatory Roviana-type headhunting culture and niche}

Roviana society depended on headhunting and raiding for captives. It was almost by definition expansionist, altering the niche or cultural environment of the region. By the end of the 19th century, populations of the New Georgia group (New Georgia, Rendova, Simbo, Rannonga, Vella Lavella, Kolombangara) had adopted the fundamental aspects of the headhunting complex (Woodford 1888) and the political organisation or at least the ability to organise which it supported. This certainly included the material manifestations of the bakiha and other shell valuables, skull shrines, tomoko war canoes and canoe houses as shown in 19th-century photographs. There is clear evidence, from oral traditions and archaeological research, of the adoption of the shrine and shell valuable complex probably within the 18th century. The extent to which all of these developed together in a 'peer polity' (Renfrew 1986) type of interactive entanglement is not clear; however, the Roviana development had clearly altered the regional cultural niche. 


\section{Oral tradition}

Oral tradition collected by the missionary George Carter indicates an important history of fighting between Roviana and Vella Lavella.

During the time when Tungahanika was mbangara in Roviana Kokorapa there occurred a great fight at Roviana Island [Nusa Roviana]. Over 1000 men from Mbilua [southern Vella Lavella] came up and attacked Roviana Island. ... When the Mbilua raiding party arrived, the Roviana people were on the top of the hill (Carter 1963-Anonymous).

When a man called Kopele became chief at Mbilua he made peace between Roviana and Mbilua. He gave a native money [bakiha] to the people of Roviana for peace. This money is called 'thousand peace', and it is still kept by Inoro of Ilangana (Carter 1963-Talasasa).

The Roviana genealogical charts collected by Hocart would place Tungahanika c. 1800 CE (Schneider 1996:Figure 7).

\section{Archaeological research}

Archaeological research on Vella Lavella demonstrates dense settlement in the interior hills (McKenzie 2007; Sheppard and Walter 2014; Sheppard et al. 2010). Skull shrines with shell valuables are found along the tops of the first ridges and are the named shrines to which modern people living on the coast affiliate. In most respects, these shrines and their contents are identical to the late period shrines in Roviana. Most date within the last several hundred years while the earliest dates are late 17th century, making them younger than the oldest late period shrines in Roviana.

The coastal flats of Vella were not inhabited during the 19th century for fear of attack, although canoe houses were maintained from which headhunting expeditions were conducted in tomoko (McKinnon 1972). At the time, the islands between Roviana and Vella Lavella were depopulated by headhunting (McKinnon 1972:64) and most of Kolombangara was depopulated to the extent that much of it, like Ghizo, was claimed by the colonial government as waste land.

Research by Thomas on Rendova and Tetepare to the south and east of Roviana provides a story similar to that from Vella Lavella. In the NAN Touo region of southern Rendova, the sequence of early simple shrines without any human remains, shell valuables or ovens followed by shrines containing all of those is, according to Thomas (2009), almost identical to that in Roviana, with the exception that the late period shrines date no earlier than $1700 \mathrm{CE}$. On the island of Tetepare, just to the east of Rendova, Thomas reports a similar sequence. As in the area to the west of Roviana, the population of Tetepare was unable to survive the raiding of the 19th century and is today the largest uninhabited island in the Pacific (Thomas 2009:136).

\section{Nineteenth century and entanglement with the Western capitalist economy}

The 19th century saw new elements enter the evolutionary landscape of the western Solomons. These interacted with the established structure to first intensify it and then radically transform and replace it. Roviana's optimal central location, sheltered anchorage and the patronage of powerful Roviana chiefs made Munda, by 1875, the focus of European trade in the western Solomons (Woodford 1888). By 1886 there were six traders stationed there, on small islands off the coast of Munda. 
By 1886 traders were dealing in a variety of goods including iron, tobacco, long-handled axes and Snider rifles which they exchanged for turtle shell and copra. Turtle shell was especially sought as it was compact and fetched a good price in Sydney. In 1851 Lewis Truscott secured more than a thousand pounds of turtle shell from New Georgia, and in 1874 the trader Fergusson delivered to Sydney 1700 pounds of turtle shell accumulated by the Rendova chiefs (Bennett $1985: 46,57)$. Turtle shell provided a good return and by 1886 , three turtle shells were exchanged for a Snider rifle at Munda. By the late 1880s these were the only items which would get them 'payable quantities' of turtle shell and copra (Bennett 1985:90; McKinnon 1975:303).

In the mid-1800s turtles were common in the waters of New Georgia but the demands of trade meant that by the 1890s turtles were very scarce and had to be hunted outside of New Georgia (Bennett 1985:94; Somerville 1897:369). If turtle hunting within Roviana Lagoon could be an individual or family activity, hunting expeditions into other areas required the manpower and protection provided by chiefs (Woodford 1890). This mapped well onto the headhunting economy and combined head/turtle expeditions provided heads/captives and evidence of chiefly mana as well as the returns from the shell, including shell rings purchased from traders. These resources were then used to finance ever greater expeditions, which with the new iron axes and rifles had an increasing impact on the populations of the western Solomons (McKinnon 1975).

The following describes an expedition to hunt turtles in the Arnavon nesting sites between Choiseul and Santa Isabel as told by Gemu a Roviana chief:

One day, only a few years ago [prior to 1906], a large party came over from Roviana on a turtle hunting expedition ... and found the Lauru [Choiseul] men poaching on our hunting grounds. ... They were all killed ... Hiqava [Ingava], Vonge and Miabule [chiefs of Roviana] took part and killed many men. We took two hundred heads back to Munda. (Carter 1981:6)

People in Choiseul and Isabel retreated first to defensive positions in the interior and ultimately along the islands to the west or east away from Roviana. In Santa Isabel this is known amongst the Cheke Holo people as the time of 'flight from death' when there were often not enough people left alive to bury the dead (White 1991:89). Woodford reported in 1888 that Santa Isabel and Choiseul were nearly depopulated (Woodford 1888:375, 1890:154, 205). As can be seen in Figure 8.1 this created the present language distribution, creating a compression of languages at the far ends of the islands and a low-density population speaking one language in the impacted areas closest to Roviana.

\section{Imposition of the colonial economy}

While the intensified Roviana chiefly economy was effective in providing turtle shell to traders, the associated violence had an adverse effect on overall trade, in particular trade in copra, which depended on safe family level production in coastal locations and a benign trading environment. A change in the relations of production and shift of authority into the Western capitalist economy was needed-if Western trade was to flourish. This required suppression of the traditional Roviana political economy. During his visit to Roviana in 1880 the Methodist missionary George Brown stayed with the local traders and reported their view:

The traders were unanimous in their desire that the British Government should stop this wholesale murder, and were equally unanimous in their opinion that the presence of a small ship of war during the headhunting season, the punishment of a few ring leaders, and the confiscation of all canoes captured whilst engaged in a raid would soon stop the horrible business. (Brown 1909:342) 


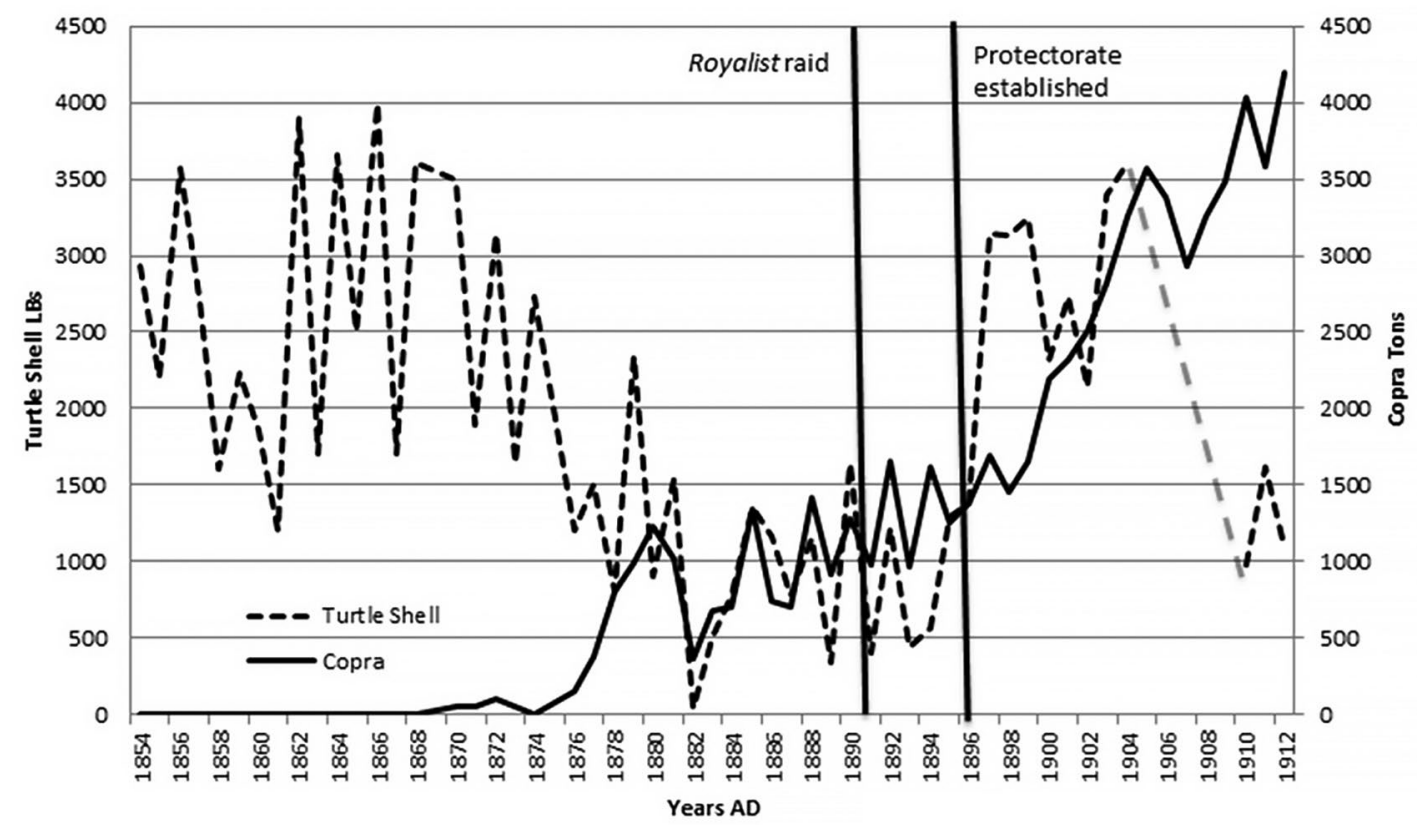

Figure 8.5. Export of copra and turtle shell from the Solomons in the 19th and early 20th centuries. Data up to 1896 is on goods landed at Sydney from Bennett (1985:Appendix 4) and subsequently from the Annual Reports of the Solomon Islands Protectorate.

Source: Peter Sheppard.

In September 1891 the British warship Royalist arrived at Roviana and sent a party of marines to investigate the murder of a local trader. When the demands to deliver the guilty parties were not met the British proceeded, over two days, to burn all the villages on Nusa Roviana and in Munda. Captain Davis estimated he destroyed 400 houses, 150 canoes and 1000 heads (Davis 1892:11).

By 1900 headhunting appears to have virtually ceased (Carter 1963:6, 9). Figure 8.5 shows the collapse in the turtle shell trade-most of which probably came from the western Solomonsand its replacement by copra at the end of the 19th century after the establishment of the colonial economy. This created a new set of relations of production, based primarily on familylevel production, which although still ultimately tied to chiefly adjudication of land use rights, was not connected to the headhunting economy.

The end of headhunting was enforced by the British but it also seems to have collapsed under the weight of its destructive impact on the region. That, along with European diseases and the creation of an environment antithetical to family-level trade in copra, saw the end of the headhunting economy (Zelenietz 1979). Chiefly mana now had to be sought through associations with traders and, within a decade, entanglement with a new cultural niche created by the Christian Church.

\section{Concluding comments: Evolution, niche construction and history}

As noted by Laland and O'Brien (2010) there is a risk for NCT explanations in archaeology to become 'just-so stories', or 'just' detailed culture histories. However, as they also note, if NCT helps us construct or think about and approach our data in a new way then that has to be useful. To that end, I think an NCT consideration of western Solomon history does help focus our attention on some overlooked aspects and highlights areas where data is needed. 
This version of history can be critiqued as very Roviana-centric; however, by the late 19th century Roviana was viewed by the British as the centre of the 'problem' and the key to securing colonial control-a view shared by the Methodists who made their regional base in Munda in 1902 (Goldie 1914). But more fundamentally the Roviana environment and its geography provided special features which made it what might be called an evolutionary hotspot. Not all geographical locations are equal (Sheppard and Walter 2008) and its central location, sheltered lagoon and very productive natural environment attracted population and potentially competition, along with interaction, to Roviana throughout its history. This created a feedback loop, through the ongoing development of the niche created by this growing population. Much of this could potentially be quantified and assessed against other areas in the western Solomons.

Beyond their geographical inheritance, the Roviana had an Austronesian inheritance providing a set of core values and ideology that created the basis for the development of hierarchy and socio-political control. The form this took was broadly Austronesian but in its details unique to the western Solomons. Elsewhere in the Oceanic Austronesian world, hierarchy correlates with economic intensification and/or control of prestige exchange (Friedman 1982). In Roviana there is no evidence of local agricultural intensification such as enhanced taro irrigation; instead there existed a networked regional economy where commodification and exchange, founded on an elaborate system of shell valuables, provided the basis for the support of hierarchy through trade (Aswani and Sheppard 2003; Sheppard and Walter 2013). Even in the dangerous environment created by headhunting, chiefly feasting could depend on transport of food by canoe from outside the language area (Hocart 1931). Roviana chiefs sought to obtain and ultimately intensify the harvest of human skulls - not taro. How one explains in evolutionary terms the selection of skulls as the tokens for a maximisation logic is unclear; however, in the Austronesian world mana or efficacy ultimately derives from humans, who are most fundamentally materialised by skulls, making them a highly valued symbol, seemingly with high selective value.

I argue that, in Roviana, the appearance of late period skull shrines, fortifications and headhunting are all related and appear after $1600 \mathrm{CE}$. Explanation for this sudden development in simple evolutionary terms (e.g. perhaps as energy sinks or costly signalling (Boone 1998)) is not obvious. Roviana people explain this development as the result of conflict between bush and coastal people and the desire for the bush chief Ididubanara to obtain the resources of the coast, as exemplified by his desire for shell valuables. Once established, the predatory nature of the Roviana chieftainship rapidly altered the cultural environment or niche in which surrounding societies functioned, resulting in the spread of the headhunting complex and associated culture. This was most probably initially confined to the New Georgia group, with some regional reassortment of population in the early 19th century.

The entanglement with the niche provided by the world economy in the 19th century created new economic drivers as chiefs linked - through the trade in turtle shell-their political economies to that of the traders attracted to the advantages provided by the dominant regional power. The hunting of turtle shell oriented the chiefs toward Choiseul and Santa Isabel, and the intensification of the headhunting complex-provided by new technologies, new sources of finance, increasing numbers of captive labourers and more effective weapons-had a devastating effect on the cultural geography of the region, resulting in the linguistic and demographic distribution seen today. Ultimately this came into conflict both with the colonial trading economy, which needed peaceful, family-level production of copra, and the power behind this new economy. The shift of power from chiefs to the new colonial government and the associated prohibition of the core features of the Roviana political economy and associated ideology effectively destroyed the foundations of 19th-century Roviana society (Rivers 1922). As related to Hocart shortly after the end of headhunting: 'Now the chiefs stop nothing' (Hocart n.d.(a)). Roviana society, and 
that of its neighbours, now entered into a new creative process of cultural niche construction, creating a colonial economy where the chiefs and people engaged with, and created societies entangled with, capitalism and the ideology of Christianity. Whether an evolutionary logic can be seen in the working out of these entanglements of colonialism is an interesting question.

\section{References}

Amherst, Lord, of Hackney and B Thomson. 1901. The discovery of the Solomon Islands by Alvaro de Mendana in 1568. Vols 1 and 2. London: Hakluyt Society.

Aswani, S. 1997. 'Customary sea tenure and artisanal fishing in the Roviana and Vonavona Lagoons, Solomon Islands: The evolutionary ecology of marine resource utilization'. Unpublished $\mathrm{PhD}$ thesis, University of Hawai i i, Honolulu.

Aswani, S. 2000. 'Changing identities: The ethnohistory of Roviana predatory headhunting'. Journal of the Polynesian Society 109 (1):39-70.

Aswani, S and P Sheppard. 2003. 'The archaeology and ethnohistory of exchange in precolonial and colonial Roviana: Gifts, commodities and inalienable possessions'. Current Anthropology. 44:S51-S78. doi.org/10.1086/377667.

Bennett, J. 1985. Wealth of the Solomons: A history of a Pacific archipelago, 1800-1978. Honolulu: University of Hawai'i Press.

Boone, J. 1998. 'The evolution of magnanimity'. Human Nature 9 (1):1-21. doi.org/10.1007/s12110998-1009-y.

Brown, G. 1899. Burial Place Rubiana. George Brown Photographer, Courtesy of the Auckland Methodist Archives, Auckland.

Brown G. 1909. George Brown, D.D.: Pioneer-missionary and explorer. London: Hodder and Stoughton.

Burt, B. 1988. 'Ábu'a 'i Kwara'ae: The meaning of tabu in a Solomon Islands society'. Mankind 18 (2):74-89.

Carter, G. 1963. 'Tunahanika’. Translation from Anonymous. In George Carter Papers. Archives University of Auckland, Auckland.

Carter, G. 1981. Ti-è varanè: Stories about people of courage from Solomon Islands. Rabaul: Unichurch.

Davis CE. 1892. Australian Station, Solomon Islands, 1891: Correspondence respecting Outrages by Natives on British Subjects and other matters, which have been under inquiry during the Year 1891, being continuation of reports of cases dealt with in former years, together with other cases which have since arisen. Sydney: Government Printer.

Dunn, M, A Terrill, G Reesink, R Foley and S Levinson. 2005. 'Structural phylogenetics and the reconstruction of ancient language history'. Science. 309 (23):2072-2075. doi.org/10.1126/science. 1114615.

Edge-Partington, T. 1907. 'Ingava, chief of Rubiana, Solomon Islands: Died 1906'. Man 7:22-23. doi.org/10.2307/2788122.

Fox, J. 1995. 'Austronesian societies and their transformations'. In The Austronesians, edited by P Bellwood, J Fox and D Tryon, 214-228. Canberra: The Australian National University.

Fox, J. 1997. 'Place and landscape in comparative Austronesian perspective'. In The poetic power of place: Comparative perspectives on Austronesian ideas of locality, edited by J Fox, 1-21. Canberra: Research School of Pacific and Asian Studies, The Australian National University. 
Friedman, J. 1982. 'Catastrophe and continuity in social evolution'. In Theory and explanation in archaeology: The Southampton conference, edited by C Renfrew, M Rowlands and B Segraves, 175-196. New York: Academic Press.

Fuentes, A. 2016. 'The extended evolutionary synthesis, ethnography, and the human niche: Toward an integrated anthropology'. Current Anthropology 57 (S13):S13-S26. doi.org/10.1086/685684.

Fuentes, A and P Wiessner. 2016. 'Reintegrating anthropology: From inside out: An introduction to supplement 13’. Current Anthropology 57 (S13):S3-S12. doi.org/10.1086/685694.

Furusawa, T and R Ohtsuka. 2009. 'The role of barrier islands in subsistence of the inhabitants of Roviana Lagoon, Solomon Islands'. Human Ecology 37 (5):629-642. doi.org/10.1007/s10745-0099266-x.

Garling, S. 2003. 'Tanga takes to the stage: Another model "Transitional” site? New evidence and a contribution to the "incised and applied relief tradition" in New Ireland'. In Pacific archaeology: Assessments and prospects, edited by C Sand, 213-233. Nouméa: Service des Musées et du Patrimoine.

Goldie, J. 1914. 'The Solomon Islands'. In A century in the Pacific, edited by J Colwell, 561-585. Sydney: William H. Beale.

Hall, A. 1964. 'Customs and culture from Kazukuru: Folklore obtained after the discovery of the shrine at Bao'. Oceania 35:127-135. doi.org/10.1002/j.1834-4461.1964.tb00839.x.

Hamilton, R, T Bird, C Gereniu, J Pita, P Ramohia, R Walter, C Goerlich and C Limpus. 2015. 'Solomon Islands largest hawksbill turtle rookery shows signs of recovery after 150 years of excessive exploitation'. PLoS ONE 10 (4):e0121435. doi.org/10.1371/journal.pone.0121435.

Hocart, AM. 1931. 'Warfare in Eddystone of the Solomon Islands'. Journal of the Royal Anthropological Institute of Great Britain and Ireland 61:301-324. doi.org/10.2307/2843922.

Hocart, AM. n.d.(a). 'Chieftainship'. Unpublished manuscript. In Hocart papers, Alexander Turnbull Library, Wellington. MS-Papers-0060.

Hocart, AM. n.d.(b). 'Trade and money'. Unpublished manuscript. In Hocart papers, Alexander Turnbull Library, Wellington. MS-Papers-0060.

Hodder, I. 2012. Entangled: An archaeology of the relationships between humans and things. Malden, MA: Wiley-Blackwell. doi.org/10.1002/9781118241912.

Keesing, R. 1985. 'Conventional metaphors and anthropological metaphysics: The problematic of cultural translation'. Journal of Anthropological Research 41 (2):201-217. doi.org/10.1086/jar.41.2.3630416.

Kirch PV and RC Green. 2001. Hawaiki, Ancestral Polynesia: An essay in historical anthropology. Cambridge: Cambridge University Press.

Laland, KN and MJ O'Brien. 2010. 'Niche construction theory and archaeology'. Journal of Archaeological Method and Theory 17(4):303-322.

Laland K, T Uller, M Feldman, K Sterelny, GB Müller, A Moczek, E Jablonka, J Odling-Smee, GA Wray, HE Hoekstra, DJ Futuyma, RE Lenski, TF Mackay, D Schluter and JE Strassmann. 2014. 'Does evolutionary theory need a rethink?' Nature 514 (7521):161. doi.org/10.1038/514161a.

Lewis, M, G Simons and C Fennig (eds). 2016. Ethnologue: Languages of the world, nineteenth edition. Dallas, Texas: SIL International.

Lichtenberk, F. 1986. 'Leadership in Proto-Oceanic society: Linguistic evidence'. Journal of the Polynesian Society 95:341-356. 
McDougall, D. 2000. 'Paths of pinauzu: Captivity and social reproduction in Ranongga'. Journal of the Polynesian Society 109 (1):99-114.

McKenzie, A. 2007. 'Ancestral skull shrines: Material dialogues of social interaction in the western Solomon Islands'. Unpublished MA thesis, University of Auckland, Auckland.

McKinnon, J. 1972. 'Bilua changes: Culture contact and its consequences, a study of the Bilua of Vella Lavella in the British Solomon Islands'. Unpublished PhD thesis, Victoria University, Wellington.

McKinnon, J. 1975. 'Tomahawks, turtles and traders: A reconstruction in the circular causation of warfare in the New Georgia group'. Oceania 45 (4):290-307. doi.org/10.1002/j.1834-4461.1975. tb01872.x.

Miller, D. 1980. 'Settlement and diversity in the Solomon Islands'. Man 15:451-466. doi.org/10.2307/ 2801344.

Nagaoka, T. 1999. 'Hope pukerane: A study of religious sites in Roviana, New Georgia, Solomon Islands'. Unpublished MA thesis, University of Auckland, Auckland.

Pawley, A. 1982. 'Rubbishman, commoner, big-man, chief? Evidence for hereditary chieftainship in Proto-Oceanic'. In Oceanic studies: Essays in honour of Aarne A. Koskinen, edited by J Siikala, 33-52. Helsinki: Finnish Anthropological Society.

Pawley, A. 2005. 'The meaning(s) of Proto Oceanic Panua'. In A polymath anthropologist: Essays in honour of Ann Chowning, edited by C Gross, H Lyons and D Counts, 211-223. Auckland: University of Auckland.

Pawley, A and M Ross. 2006. 'The prehistory of Oceanic languages: A current view'. In The Austronesians: Historical and comparative perspectives, edited by P Bellwood, J Fox and D Tryon, 43-80. Canberra: ANU E Press.

Renfrew, C. 1986. 'Introduction: Peer polity interaction and socio-political change'. In Peer polity interaction and socio-political change, edited by C Renfrew and J Cherry, 1-18. Cambridge: Cambridge University Press.

Reuter, TA. 2006. 'Land and territory in the Austronesian world'. In Sharing the Earth, carving up the land: Territorial categories and institutions in the Austronesian world, edited by T Reuter, 11-38. Canberra: ANU E Press.

Ribbe, C. 1903. Zwei jahre unter den Kannibalen der Salomo-Inseln. Dresden: Beyer.

Richards, R and K Roga. 2004. 'Barava: Land title deeds in fossil shell from the western Solomon Islands'. Tuhinga: Records of the museum of New Zealand Te Papa Tongarewa 15:17-26.

Rivers, W. 1922. Essays on the depopulation of Melanesia. Cambridge: Cambridge University Press.

Roe, D. 2000. 'Maritime, coastal and inland societies in Island Melanesia: The bush-saltwater divide in Solomon Islands and Vanuatu'. In East of Wallace's Line: Studies of past and present maritime cultures of the Indo-Pacific region, edited by S O'Connor and P Veth, 197-222A. Rotterdam: A. Balkema.

Ross, M. 1988. Proto Oceanic and the Austronesian languages of western Melanesia. Canberra: Pacific Linguistics.

Ross, M. 2010. 'Lexical history in the Northwest Solomonic languages: Evidence for two waves of Oceanic settlement in Bougainville and the northwest Solomons'. In A journey through Austronesian and Papuan linguistic and cultural space: Papers in honour of Andrew Pawley, edited by J Bowden, NP Himmelmann and M Ross, 245-270. Canberra: Pacific Linguistics.

Scaglion, R. 1996. 'Chiefly models in Papua New Guinea'. The Contemporary Pacific 8 (1):1-31. 
Schneider, G. 1996. 'Land dispute and tradition in Munda, Roviana Lagoon, New Georgia, Solomon Islands from headhunting to the quest for the control of land'. Unpublished $\mathrm{PhD}$ thesis, University of Cambridge, Cambridge.

Sheppard, P, S Aswani, R Walter and T Nagaoka. 2002. 'Cultural sediment: The nature of a cultural landscape in Roviana Lagoon'. In Pacific landscapes: Archaeological approaches, edited by T Ladefoged and M Graves, 35-61. Bearsville, California: Easter Island Foundation Press.

Sheppard, P and R Walter. 2006. 'A revised model of Solomon Islands culture history'. Journal of the Polynesian Society 115:47-76.

Sheppard, P and R Walter. 2008. 'The sea is not land: Comments on the archaeology of islands in the western Solomons'. In Comparative island archaeologies, edited by J Connolly and M Campbell, 167-178. Oxford: BAR International Series.

Sheppard, P and R Walter. 2009. 'Inter-tidal late Lapita sites and geotectonics in the western Solomons'. In Lapita: Ancestors and descendants, edited by P Sheppard, T Thomas and G Summerhayes, 73-100. Auckland: New Zealand Archaeological Association.

Sheppard, P and R Walter. 2013. 'Diversity and networked interdependence in the western Solomons'. In Pacific archaeology: Documenting the past 50,000 years, papers from the 2011 Lapita Pacific archaeology conference, edited by G Summerhayes and B Hallie, 138-147. Dunedin: University of Otago Studies in Archaeology.

Sheppard, P and R Walter. 2014. 'Shell valuables and history in Roviana and Vella Lavella'. In The things we value: Culture and history in the Solomon Islands, edited by B Burt and L Bolton, 32-45. London: Sean Kingston Publishing.

Sheppard, P, R Walter and T Nagaoka. 2000. 'The archaeology of head-hunting in Roviana Lagoon, New Georgia, Solomon Islands'. Journal of the Polynesian Society 109 (1):9-37.

Sheppard, P, R Walter and K Roga. 2010. 'Friends, relatives, and enemies: The archaeology and history of interaction among Austronesian and NAN speakers in the western Solomons'. In A journey through Austronesian and Papuan linguistic and cultural space: Papers in honour of Andrew Pawley, edited by J Bowden, N Himmelmann and M Ross, 95-112. Canberra: Pacific Linguistics Press.

Shineberg, D. 1971. The trading voyages of Andrew Cheyne, 1841-1844. Canberra: The Australian National University.

Shore, B. 1996. Culture in mind: Cognition, culture and the problem of meaning. Oxford: Oxford University Press.

Somerville, B. 1897. 'Ethnographical notes in New Georgia, Solomon Islands'. Journal of the Royal Anthropological Institute of Great Britain and Ireland 26 (4):357-413.

Spriggs, M. 1997. The island Melanesians. Oxford: Blackwell.

Thomas, N. 1991. Entangled objects: Exchange, material culture and colonialism in the Pacific. Cambridge, Massachusetts: Harvard University Press.

Thomas, T. 2009. 'Communities of practice in the archaeological record of New Georgia, Rendova and Tetepare'. In Lapita: Ancestors and descendants, edited by P Sheppard, T Thomas and G Summerhayes, 119-145. NZAA Monograph 28. Auckland: New Zealand Archaeological Association.

Vischer, MP. 2009. Precedence: Social differentiation in the Austronesian world. Canberra: ANU E Press. doi.org/10.22459/P.05.2009.

Walter, R and P Sheppard. 2001. 'Nusa Roviana: The archaeology of a Melanesian chiefdom'. Journal of Field Archaeology 27 (3):295-318. doi.org/10.1179/jfa.2000.27.3.295. 
Waterhouse, J. 1949. A Roviana and English dictionary, with English-Roviana index and list of natural history objects and appendix of old customs, revised and enlarged by L M Jones. Sydney: Epworth Printing and Publishing House.

Welsch, R. 1998. An American anthropologist in Melanesia: A.B. Lewis and the Joseph N. Field South Pacific expedition, 1909-1913. Honolulu: University of Hawai'i Press.

White, G. 1991. Identity through history: Living stories in a Solomon Islands society. Cambridge: Cambridge University Press. doi.org/10.1017/CBO9780511621895.

Wickler, S. 2001. The prehistory of Buka: A stepping stone island in the northern Solomons. Canberra: Department of Archaeology and Natural History and Centre for Archaeological Research, The Australian National University.

Woodford, CM. 1888. 'Exploration of the Solomon Islands'. Proceedings of the Royal Geographical Society $10: 351-376$.

Woodford, C. 1890. A naturalist among the head-hunters. London: George Phillip and Son.

Woodford, C. 1909. 'The canoes of the British Solomon Islands'. Journal Royal Anthropological. Institute 9:505-516. doi.org/10.2307/2843216.

Zelenietz, M. 1979. 'The end of head hunting in New Georgia'. In The pacification of Melanesia, edited by M Rodman and M Cooper, 91-108. Ann Arbor: University of Michigan Press. 
This text is taken from Archaeologies of Island Melanesia: Current approaches to landscapes, exchange and practice, edited by Mathieu Leclerc and James Flexner, published 2019 by ANU Press, The Australian National University, Canberra, Australia.

doi.org/10.22459/TA51.2019.08 